\title{
KONFLIK MANAJEMEN ANTARA PENGELOLA DAN MASYARAKAT DI TAHURA DJUANDA, BANDUNG, JAWA BARAT
}

\author{
Dian Fitriyana \\ Email: dfitry9@gmail.com
}

\begin{abstract}
The Grand Forest Park of Ir. H. Djuanda is a popular ecotourism in Bandung, West Java. The management is conducted by the Management Center helped by the locals. However, it has been disharmonious relationship between the park management and the local community. This article analyses conflict between the management and the community. It discusses causes, implications and solutions to the conflicts. The data were taken from observation, interviews, and documentions which were analysed using qualitative approach. The study shows that the causes of conflict are policy differences, frequent change in management leadership, lack of dissemination of empowerment programs to the people, factors of lower people's education, and narrow-minded of people's. The implications are both negative and positive to the empowerment programs.
\end{abstract}

Keywords : conflict of management, ecotourism, community empowerment, the Djuanda Grand Forest Park

\section{Pendahuluan}

Kota Bandung di Jawa Barat sejak lama memiliki daya tarik yang kuat untuk wisatawan berkunjung. Pada zaman colonial, kota ini dijuluki Paris van Java, yang menjadi tujuan untuk berrekreasi bagi orang-orang Eropa yang bekerja untuk pemerintahan kolonial. Dibandingkan suasana pusat pemerintahan kolonial di Batavia (kini Jakarta), Bandung memiliki udara yang sejuk dan alam yang indah. Dewasa ini, daya tarik Bandung bertambah, dikenal sebagai kota belanja, dengan mall, factory outlet, wisata kuliner, wisata budaya, wisata rekreasi, dan tentu juga daya tarik wisata alam.

Salah satu objek wisata alam yang ada di Kota Bandung adalah Taman Hutan Raya Ir. H. Djuanda (selanjutnya disingkat dengan nama Tahura Djuanda). Tahura Djuanda merupakan kawasan wisata yang memiliki banyak potensi alam sebagai daya tarik wisata. Kawasan ini dinamakan Tahura Djuanda, karena pada saat didirikan dan diresmikan pada tanggal 14 Januari 1985 oleh Presiden RI II bertepatan dengan kelahiran Ir. H. Djuanda, tokoh sekaligus pahlawan nasional yang berasal dari Tasikmalaya, 
Jawa Barat. Terletak kawasan wisata yang terletak di Bandung Utara yang berjarak $\pm 7 \mathrm{~km}$ dari pusat kota. Secara administratif berada di wilayah Desa Ciburial Kecamatan Cimenyan Kabupaten Bandung. (Balai Pengelolaan Tahura Djuanda, tahun 2014).

Potensi wisata yang dimiliki Tahura Djuanda meliputi Monumen Ir. H. Djuanda, Gua Jepang dan Gua Belanda, Air Terjun Curug Omas, Air Terjun Curug Lalay, Air Terjun Curug Dago, Prasasti Raja Thailand, Keragaman Flora dan Fauna. Semua potensi wisata tersebut sangat penting dalam pengelolaan dan pengembangan ekowisata. Keberhasilan pengelolaan kawasan wisata sangat tergantung dari sikap positif masyarakat terhadap keberadaan Tahura Djuanda. Memberdayakan masyarakat sekitar dalam pengelolaan ekowisata merupakan bentuk partisipasi langsung dalam pengelolaan kawasan wisata alam. (Balai Pengelolaan Tahura Djuanda, tahun 2014).

Partisipasi masyarakat merupakan kunci utama dalam pengelolaan kawasan wisata dan memberikan peluang terjalinnya hubungan kerjasama antara masyarakat dengan pengelola Tahura Djuanda. Kerja sama tersebut mengarah kepada kegiatan sosial sesuai dengan konsep ekowisata yang terdiri atas komponen-komponen pelestarian lingkungan alam, budaya, peningkatan partisipasi masyarakat, dan peningkatan pertumbuhan ekonomi lokal. Berdasarkan data monografi Desa, masyarakat di sekitar Tahura Djuanda sebagian besar bekerja sebagai petani dan usaha swasta dengan tingkat pendidikan rata-rata SD dan SMP. Pengetahuan pariwisata dan pentingnya menjaga lingkungan masih kurang, hal ini terlihat dari keterlibatan masyarakat dalam pengelolaan ekowisata (Foto 1).

Tahura Djuanda sebagai destinasi wisata tergolong belum memadai, beberapa sarana dan prasarana seperti tempat sampah yang rusak, jalan setapak tidak terawat, pedagang kaki lima tidak teratur, kios-kios pedagang yang belum dikelola dengan baik dan banyaknya kendaraan bermotor (ojek) yang masuk ke dalam kawasan mengakibatkan pencemaran lingkungan, sampah plastik berada di sekitar air terjun belum ada tindak lanjut. Selain itu, program pemberdayaan masyarakat di Tahura Djuanda dilaksanakan secara rutin tetapi masyarakat belum sepenuhnya mendapat apresiasi yang positif. Hal tersebut disebabkan mata pencaharian yang diperoleh masih belum mencukupi kebutuhan masyarakat setempat, sehingga mengakibatkan konflik manajemen antara pengelola dengan masyarakat.

Pengelolaan ekowisata yang melibatkan masyarakat sangat penting untuk dapat mengembangkan atraksi wisata baru sebagai alternatif daya tarik wisata. Tujuannya untuk dapat meningkatkan jumlah kunjungan wisatawan dan sekaligus dapat membuka lapangan pekerjaan baru untuk masyarakat sekitar kawasan Tahura Djuanda. Kenyataan di lapangan terdapat kesenjangan antara pengelola dan masyarakat sekitar kawasan 


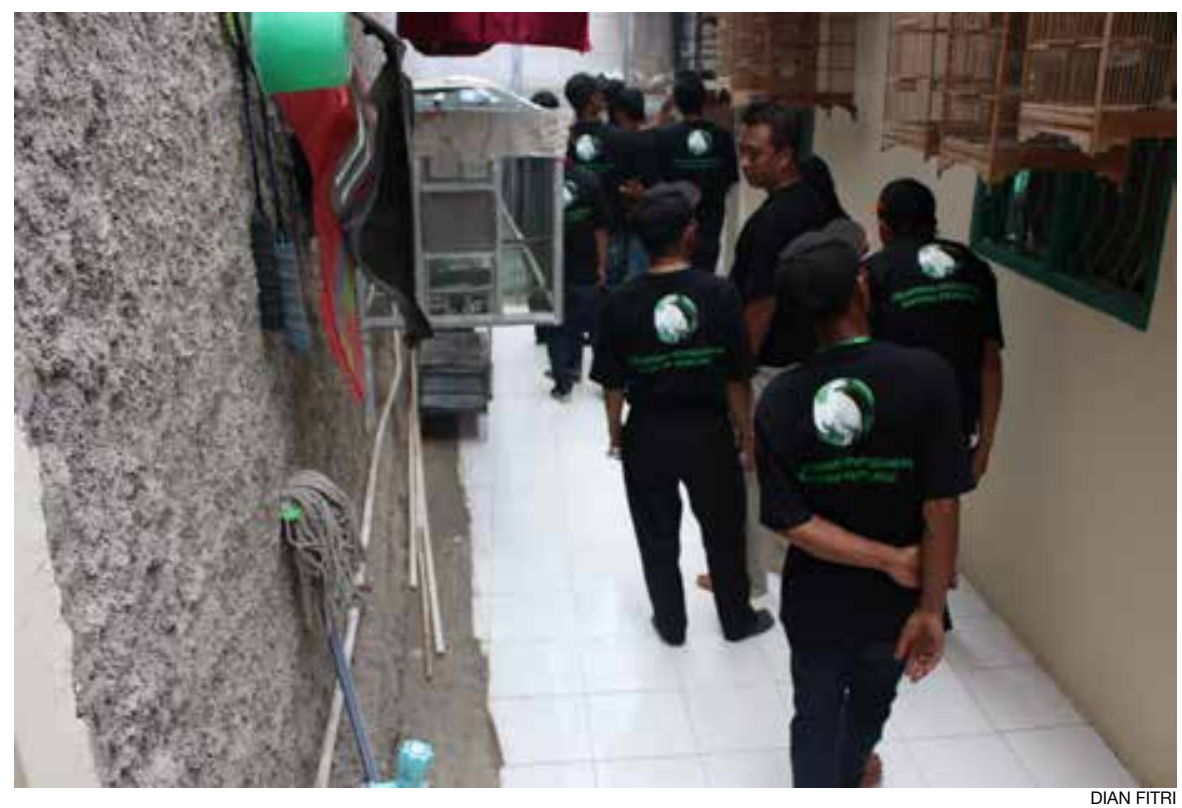

Foto 1. Partisipasi masyarakat dalam program pelatihan pemberdayaan.

yang mengakibatkan konflik manajemen. Hal tersebut, sangat mengganggu kunjungan wisatawan untuk menikmati alam karena masyarakat belum memiliki kesadaran untuk berpartisipasi aktif dalam menjaga dan melestarikan sumber daya kekayaan alam di Tahura Djuanda, yang sesungguhnya menjadi sumber pendapatan masyarakat setempat.

Dengan demikian, permasalahan yang diangkat dalam penelitian ini adalah; faktor-faktor apakah yang menyebabkan konflik dalam pengelolaan ekowisata berbasis pemberdayaan masyarakat, bagaimana implikasi konflik dalam pengelolaan ekowisata berbasis pemberdayaan masyarakat, dan bagaimana solusi penyelesaian konflik dalam pengelolaan ekowisata berbasis pemberdayaan masyarakat di Tahura Djuanda.

\section{Teori dan Metode}

Ada dua teori yang digunakan dalam analisis persoalan dalam artikel ini. Teori konflik dari Fisher (2001) digunakan untuk menyelesaikan permasalahan antara pengelola dan masyarakat di Tahura Djuanda secara berlanjut dan tidak merugikan kedua belah pihak. Teori Community Based Tourism dari Bambang Sunaryo (2013) digunakan menganalisis faktor penyebab dan implikasi konflik dalam pengelolaan ekowisata, sedangkan teori Manajemen dari Flippo (2002) untuk mengetahui solusi penyelesaian konflik dalam pengelolaan ekowisata berbasis pemberdayaan masyarakat melalui tahap perencanaan, pengorganisasian, pengarahan, pengawasan, 
dan evaluasi setelah penerapan fungsi manajemen.

Artikel ini menggunakan metode deskriptif kualitatif. Teknik penentuan informan menggunakan purposive sampling dengan informan kuncinya adalah pengelola, dan masyarakat yang berada di sekitar Tahura Djuanda. Pengumpulan data penelitian dilakukan melalui observasi, wawancara dan dokumentasi. Data yang sudah terkumpul dirangkum atau diklasifikasikan dan dipilih berdasarkan permasalahan yang dikaji, tahapan kedua adalah penyajian data yang akan dilakukan dalam bentuk gambar, tabel, dan narasi kemudian dilanjutkan dengan tahapan ketiga penarikan kesimpulan atau disebut dengan verifikasi.

\section{Faktor-faktor Penyebab Konflik di Tahura Djuanda}

Faktor-faktor penyebab konflik dalam pengelolaan ekowisata berbasis pemberdayaan masyarakat di Tahura Djuanda Bandung, terdiri dari: penyebab konflik dari pengelola dan penyebab konflik dari masyarakat.

\subsection{Penyebab Konflik dari Pengelola}

Penyebab konflik dari pengelola dibagi menjadi tiga bagian, yaitu a) kebijakan, b) kepemimpinan, dan c) kurangnya sosialisasi.

\section{a. Kebijakan}

Pada Tahun 1985 Tahura Djuanda dikelola oleh Perum Perhutani, masyarakat sekitar yang berjualan di luar kawasan Tahura Djuanda direlokasi ke Tahura Djuanda untuk berdagang. Pada pertengahan tahun 1985 masyarakat mulai bekerja dalam bidang yang beragam, seperti pedagang, pemandu wisata tukang ojek, tukang senter, penjaga kemanan serta penjaga kebersihan lingkungan bersama-sama dengan masyarakat setempat.

Kebijakan lain yang diberlakukan oleh Perum Perhutani adalah memberikan subsidi sebagai modal kepada masyarakat setempat khususnya para pedagang sebesar Rp. 200.000,- untuk mendirikan warung di sekitar kawasan Tahura Djuanda. Tetapi, pada tahun 2003 sampai tahun 2015 Balai Pengelolaan tidak menerapkan pemberian modal tersebut kepada masyarakat sehingga mengakibatkan konflik. Kebijakan lain yang diberlakukan oleh Balai Pengelolaan yaitu adanya pembatasan kendaraan roda dua (ojek) yang menjadi salah satu mata pencaharian masyarakat setempat. Kebijakan tersebut dilakukan oleh Balai Pengelolaan dengan tujuan supaya masyarakat sekitar kawasan bisa mandiri tanpa mengandalkan pengelola, seperti yang dikemukakan oleh Bapak Hasan (Kepala Seksi Pemanfaatan Tahura Djuanda) menyatakan sebagai berikut:

"Masyarakat Tahura Djuanda harus bekerja secara mandiri, untuk itu kami membuat program pemberdayaan masyarakat supaya masyarakat mempunyai 
kemampuan yang lebih dan bisa menghasilkan uang”. (Wawancara dengan Bapak Hasan, 5 Mei 2015).

Pernyataan tersebut menyiratkan bahwa orang yang mampu harus diberikan kesadaran dan pemahaman bahwa kemampuan individu muncul kalau diimbangi dengan kerja keras dan mau belajar. Hal ini sesuai dengan konsep pemberdayaan masyarakat bahwa pemberdayaan identik dengan pengembangan sumber daya manusia yang tidak hanya membentuk manusia profesional dan terampil sesuai dengan kebutuhan sistem untuk dapat memberikan kontribusi di dalam proses pembangunan tetapi menekankan pada kemampuan manusia untuk dapat mengaktualisasi diri (Tjokrowinoto, 2001:29).

\section{b. Kepemimpinan}

Pergantian kepemimpinan di Tahura Djuanda dilakukan sebanyak enam kali, yaitu periode pertama tahun 2002 sampai periode keenam tahun 2011 sampai dengan sekarang. Dalam tiga belas tahun Tahura Djuanda telah berganti kepemimpinan sebanyak enam kali. Seringnya pergantian kepemimpinan dikarenakan faktor internal yang bersumber dari Dinas Kehutanan, karena Dinas Kehutanan yang mempunyai kewenangan atas pergantian dan pengaturan kepemimpinan untuk mengelola Tahura Djuanda. Pergantian kepemimpinan yang terlalu sering berdampak pada kondisi Tahura Djuanda.

Berdasarkan hasil wawancara dan observasi yang telah dilakukan di lapangan, seperti pernyataan Ibu Iwih menyatakan sebagai berikut:

"Saya tidak puas dengan pengelolaan sekarang karena Balai Pengelolaan tidak peka pada pedagang di Tahura Djuanda, tidak seperti dulu waktu dikelola Perum Perhutani, setiap bulan dikasih uang Rp. 200.00o, tetapi pengelola sekarang tidak kasih uang untuk modal berdagang dan kondisi jalan sekarang rusak, jalan menuju Goa Jepang dan Belanda tidak diperbaiki”. (Wawancara dengan Ibu Wiwih 12 Mei 2015).

Pernyataan tersebut menyiratkan terkait dengan kondisi jalan di kawasan Tahura Djuanda khususnya yang menuju objek wisata belum ada perbaikan, serta kondisi warung pedagang kurang layak dan belum sesuai dengan konsep ekowisata. Menurut Boo (1992) ekowisata harus dapat dikelola dengan cara yang dapat menjamin keberlangsungan (daya hidup) lingkungan alam dan budaya yang terkait di daerah tempat kegiatan ekowisata, sambil menerapkan cara mengelola yang baik untuk menjamin kelangsungan hidup ekonomi masyarakat. 


\section{c. Kurangnya Sosialisasi}

Kurangnya sosialisasi di dalam program Pelatihan Pemberdayaan Masyarakat merupakan upaya yang dilakukan oleh pihak pengelola dalam memberdayakan masyarakat sekitar, dengan cara membuat beberapa kegiatan program pemberdayaan masyarakat yang meliputi kegiatan peningkatan usaha produktif kelompok masyarakat, kolaborasi perlindungan kawasan dan pemanfaatan jasa lingkungan untuk kepentingan sosial. Pada kenyataan dilapangan, masih banyak masyarakat yang belum mendapatkan kesempatan untuk mengikuti program pelatihan tersebut, karena pengelola membatasi peserta yang akan ikut program pelatihan dikarenakan keterbatasan tempat. Hal tersebut membuat masyarakat yang tidak mengikuti program tersebut merasa tidak dianggap dimana masyarakat sekitar Tahura Djuanda merasa tidak adil dikarenakan yang mengikuti program pemberdayaan hanya orang-orang pilihan Tahura Djuanda.

Hal tersebut dikarenakan kurangnya komunikasi dan koordinasi antara pengelola dengan masyarakat dan sekaligus menjadi penyebab konflik interaksi personal dengan masyarakat. Fisher (2001), yang mengatakan bahwa konflik timbul karena ketidakseimbangan antara hubunganhubungan itu contohnya, kesenjangan status sosial, kurang meratanya kemakmuran dan akses yang tidak seimbang terhadap sumber daya, serta kekuasaan yang tidak seimbang, yang kemudian menimbulkan masalahmasalah seperti diskriminasi, pengangguran, kemiskinan, penindasan, dan kejahatan.

\subsection{Penyebab Konflik dari Masyarakat}

Penyebab konflik dari masyarakat antara lain: a) pendidikan, b) pola pikir, dan c) pendapatan.

\section{a. Pendidikan}

Tingkat pendidikan masyarakat sekitar Tahura Djuanda termasuk ke dalam kategori rendah. Pendidikan merupakan faktor penting dalam keberhasilan pembangunan kawasan wisata. Semakin tinggi tingkat pendidikan masyarakat maka semakin tinggi pula tingkat keterampilan dan kualitas sumber daya manusianya. Dari penelitian yang telah dilakukan bahwa pemahaman masyarakat tentang program pelatihan yang diberikan oleh pengelola masih terbatas, hal tersebut dikarenakan tidak semua masyarakat mengikuti program pelatihan karena ketebatasan atau hanya berfikir untuk jangka pendek. Bapak Imam Santoso (Kepala Balai Pengelolaan Tahura Djuanda) menyatakan sebagai berikut:

"Masyarakat diberikan program pelatihan supaya mereka mendapatkan keterampilan dan bisa menghasilkan pendapatan sendiri, tetapi setelah program 
pelatihan itu selesai masyarakat kembali seperti semula tidak menerapkan pelatihan yang sudah dijalankan di kehidupan sehari-hari di kawasan Tahura Djuanda”. (Wawancara dengan Bapak Imam Santoso 14 April 2015).

Pernyataantersebutmenyiratkanbahwaprogrampelatihanyang diberikan kepada masyarakat belum diterima secara maksimal oleh masyarakat. Hal tersebut dikarenakan masyarakat belum benar-benar mengerti dengan manfaat yang diperoleh dari program pelatihan masyarakat itu sendiri dan masyarakat belum merasakan hasil dari program pemberdayaan tersebut.

\section{b. Pola Pikir}

Pola pikir masyarakat dimana terkait dengan program pelatihan pemberdayaan tersebut memakan waktu yang lama untuk mendapatkan ekonomi masyarakat. Pelatihan ini diupayakan untuk masyarakat supaya mempunyai kemampuan dalam berwirausaha dan secara perlahan mengubah pola pikir masyarakat supaya tidak primitif. Kartasasmita (1997) mengatakan bahwa tujuan akhir pemberdayaan masyarakat adalah membuat masyarakat mandiri, berdaya, dan membangun untuk memajukan diri ke arah kehidupan yang lebih baik secara berkesinambungan.

\section{c. Pendapatan}

Pendapatan masyarakat, memanfaatkan Tahura Djuanda sebagai sumber pendapatan masyarakat setempat yang bersumber dari wisatawan yang datang ke Tahura Djuanda. Pengeluaran wisatawan yang dilakukan di kawasan wisata Tahura Djuanda menjadi sumber pendapatan bagi masyarakat lokal. Pendapatan berasal dari usaha-usaha jasa seperti ojek, pemandu wisata, penyewaan senter, dan berjualan. Jumlah usaha jasa di dominasi oleh tukang ojek, jasa transportasi ojek diperlukan untuk mengantar wisatawan karena jarak dari satu kawasan wisata cukup jauh. Tidak adanya izin dari masyarakat kepada pengelola sebagai tukang ojek dibarengi dengan semakin banyaknya jumlah kendaraan beroda dua yaitu ojek tanpa adanya pembatasan jumlah berdampak pada kondisi lingkungan.

\section{Implikasi Konflik di Tahura Djuanda}

Implikasi konflik di Tahura Djuanda Bandung terdiri dari: a) implikasi ekonomi, b) implikasi lingkungan, c) implikasi sosial.

\section{a. Implikasi Ekonomi}

Aspek ekonomi, penurunan jumlah wisatawan berdampak pada pendapatan Tahura Djuanda yang bersumber dari penjualan tiket masuk, karcis parkir, penyewaan tempat untuk kegiatan preweding dan penggunaan sarana dan prasarana. Selain itu adanya masyarakat yang melakukan pemaksaan dalam penyewaan senter untuk masuk ke dalam objek wisata 


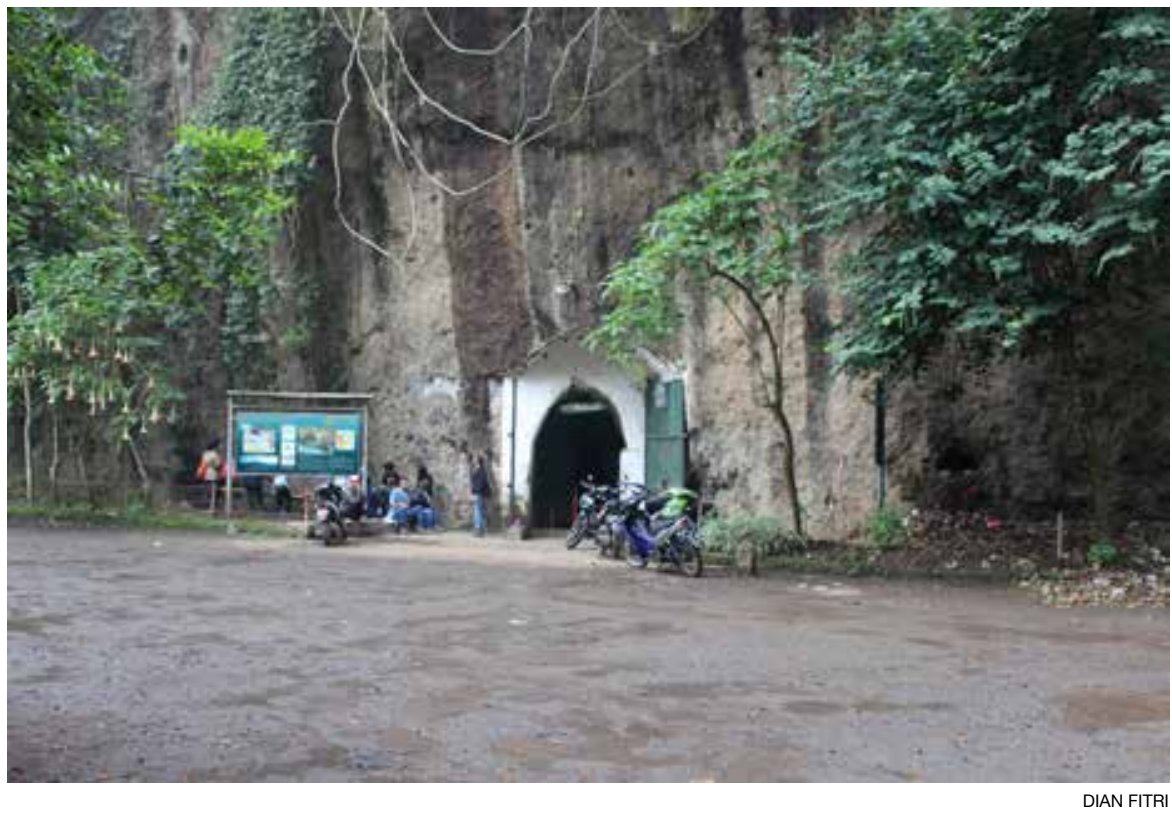

Foto 2. Goa Jepang Tahura Djuanda salah satu sumber pendapatan masyarakat.

di Tahura Djuanda yaitu Goa Jepang dan Goa Belanda membuat wisatawan tidak nyaman dan menimbulkan penurunan retribusi untuk kawasan wisata Tahura Djuanda itu sendiri (Foto 2). Sebagaimana yang telah dikemukakan oleh Natori (2001) bahwa menjaga kepuasan wisatawan melalui pelayanan yang baik, pengadaan informasi yang efektif, efesien, tepat guna, serta mengutamankan kenyamanan bagi wisatawan.

\section{b. Implikasi Lingkungan}

Implikasi lingkungan terjadinya pencemaran udara, pencemaran air, dan kerusakan lingkungan. Indikator dari pencemaran udara disebabkan oleh asap kendaraan roda dua (Ojek) yang menjadi alat transportasi untuk wisatawan sekaligus menjadi pemasukan ekonomi bagi masyarakat setempat, namum di pihak lain pengelola kawasan Tahura Djuanda menjadi terkena dampak negatif dikarenakan terlalu banyaknya jumlah ojek di dalam kawasan Tahura Djuanda. Pencemaran udara di suatu kawasan wisata yang tidak dikelola dengan baik, pemanfaatan kendaraan yang berlebihan untuk transportasi wisata akan dapat menimbulkan polusi udara yang berupa kandungan karbon di udara yang berlebih dan terjadi kebisingan udara yang menimbulkan polusi kebisingan serta polusi pemandangan seperti penataan fasilitas yang kurang baik di kawasan wisata Tahura Djuanda.

Indikator pencemaran air disebabkan oleh limbah yang berasal dari pemukiman masyarakat yang berada di sekitar Tahura Djuanda, dimana limbah tersebut terbuang melalui sungai Cikapundung yang alirannya 
menuju kawasan Tahura Djuanda melalui curug atau air terjun yang menjadi daya tarik wisata. Indikator kerusakan lingkungan disebabkan oleh sampah plastik yang berada di sekitar air terjun, yang sampai sekarang belum ada upaya pengelola dalam mengatasi masalah sampah plastik tersebut. Konflik juga berimplikasi terhadap kerusakan lingkungan dan situs peninggalan sejarah yaitu prasasti Thailand dan monumen Ir. H. Djuanda, dikhawatirkan masyarakat yang mengalami konflik dengan pengelola akan merusak lingkungan sekitar seperti pemanfaatan lahan dan pengembangan kepariwisataan yang berlebihan dan tidak terkontrol yang akan dapat menimbulkan degradasi lingkungan seperti hilangnya berbagai jenis satwa, vegetasi, kerusakan situs, dan hutan.

Hal tersebut sesuai dengan pendapat Wardiyanto (2011), yang mengemukakan bahwa dampak negatif yang kemungkinan ditimbulkan dari lingkungan alam adalah polusi udara, air, dan udara, serta suara, permasalahan sampah, kerusakan ekologis, kerusakan lingkungan, rusaknya situs arkeologis dan historis, masalah penggunaan lahan khususnya di sekitar atraksi wisata yang umumnya menjadi tidak lagi memperhatikan aspek keamanan dan keindahan.

\section{c. Implikasi Sosial}

Implikasi sosial yang timbul dapat berupa potensi konflik antara pengelola dengan masyarakat lokal yang memiliki pola pikir dan kebiasaan yang berbeda. Implikasi konflik yang ditimbulkan dengan adanya kegiatan wisata alam di Tahura Djuanda adalah terjadinya penurunan dari segi nilainilai sosial pada masyarakat. Penurunan tersebut dapat berupa kesenjangan sosial yang makin tinggi ataupun menipisnya kekerabatan dan budaya tolong menolong dalam kehidupan sehari-hari. Pengaruh ini diduga datang akibat meningkatnya kebutuhan hidup dan persaingan yang semakin tidak sehat diantara masyarakat tersebut, mengubah pola pikir masyarakat yang hanya mementingkan pendapatan, lingkungan maupun peningkatan taraf hidup masyarakat sekitar kawasan Tahura Djuanda.

\section{Solusi Konflik di Tahura Djuanda}

Tahura Djuanda memiliki luas 526,98 hektar yang langsung berbatasan dengan tempat tinggal masyarakat, dapat dikembangkan untuk kegiatan pariwisata dengan membuka lapangan pekerjaan yang baru untuk masyarakat supaya masyarakat Tahura Djuanda tidak terpaku pada beberapa profesi. Kawasan Tahura Djuanda dapat dikembangkan dengan cara pembuatan zonasi dengan pengaturan areal berdasarkan fungsi dan pemanfaatannya dengan tujuan untuk menjaga kelestarian lingkungan alam, memberikan kemudahan, dan kenyamanan untuk wisatawan yang berkunjung.

Penentuan zonasi dikawasan Tahura Djuanda dapat didasarkan pada 
objek-objek wisata atau atraksi wisata seperti memperluas area trekking, wisata outbond seperti camping, flaying fox, bangunan dan fasilitas-fasilitas penunjang lainnya yang mendukung kegiatan ekowisata seperti pusat informasi, perbaikan jalan. Memperbaiki sarana dan prasarana sebagai penunjang kegiatan pariwisata dengan mengadakan jasa transportasi yang ramah lingkungan, seperti adanya mobil wisata, wisata berkuda, dan sepeda, dikelola oleh Balai pengelolaan dengan melibatkan masyarakat setempat.

Solusi konflik membutuhkan strategi yang tepat dengan menerapkan fungsi manajemen di dalam pengelolaannya. Pertama, perencanaan program kegiatan oleh pengelola Tahura Djuanda dapat memberikan informasi secara langsung kepada masyarakat, melakukan komunikasi, dan mendata masyarakat yang akan mengikuti program pemberdayaan masyarakat, serta mangatur jadwal kegiatan secara bertahap supaya program pemberdayaan yang dilaksanakan berjalan secara optimal, dan dapat diimplementasikan di dalam kehidupan sehari-hari.

Kedua, pengorganisasian kelembagaan, cara membuat struktur organisasi dan masyarakat terlibat di dalamnya dengan memilih pimpinan dalam anggota masyarakat yang bertugas untuk melaporkan segala kegiatan kepada pengelola kawasan Tahura Djuanda. Hal tersebut supaya tidak terjadi kesalapahaman antara pengelola dengan masyarakat dalam kegiatan pariwisata yang dilakukan di Tahura Djuanda.

Ketiga, memberikan pengarahan terkait dengan kegiatan-kegiatan yang diperbolehkan dan dilarang, dan memberikan penjelasan tentang dampak positif dan negatif kepada masyarakat Tahura Djuanda supaya tetap terjaga kelestarian lingkungan. Keempat, pengawasan dilakukan oleh pengelola Tahura Djuanda sebagai penerima kegiatan pariwisata, pendukung, sekaligus pelaku bertujuan untuk melestarikan lingkungan yang melibatkan masyarakat Tahura Djuanda. Kelima, Evaluasi dilakukan untuk mengetahui sejauh mana kondisi di lapangan dan keberhasilan program-program yang dibuat oleh pengelola dengan melibatkan masyarakat sekitar berjalan dengan baik, setelah diterapkan fungsi-fungsi manajemen di kawasan Tahura Djuanda.

Penyelesaian konflik dilakukan melalui tiga tahap yaitu melakukan negosiasi antara pengelola dengan masyarakat yang tujuannya adalah untuk mendapatkan atau mencapai kesepakatan (win-win solution). Pengendalian konflik dengan mendatangkan mediator sebagai media dalam menyelesaikan konflik, yaitu Dinas Kehutanan sebagai pihak ke-3 memberikan pertimbangan-pertimbangan terkait dengan pengelolaan Tahura Djuanda dan pihak ke 3 yang berwenang untuk mengambil keputusan penyelesaian konflik yang terjadi antara pengelola dan masyarakat di Tahura Djuanda. 


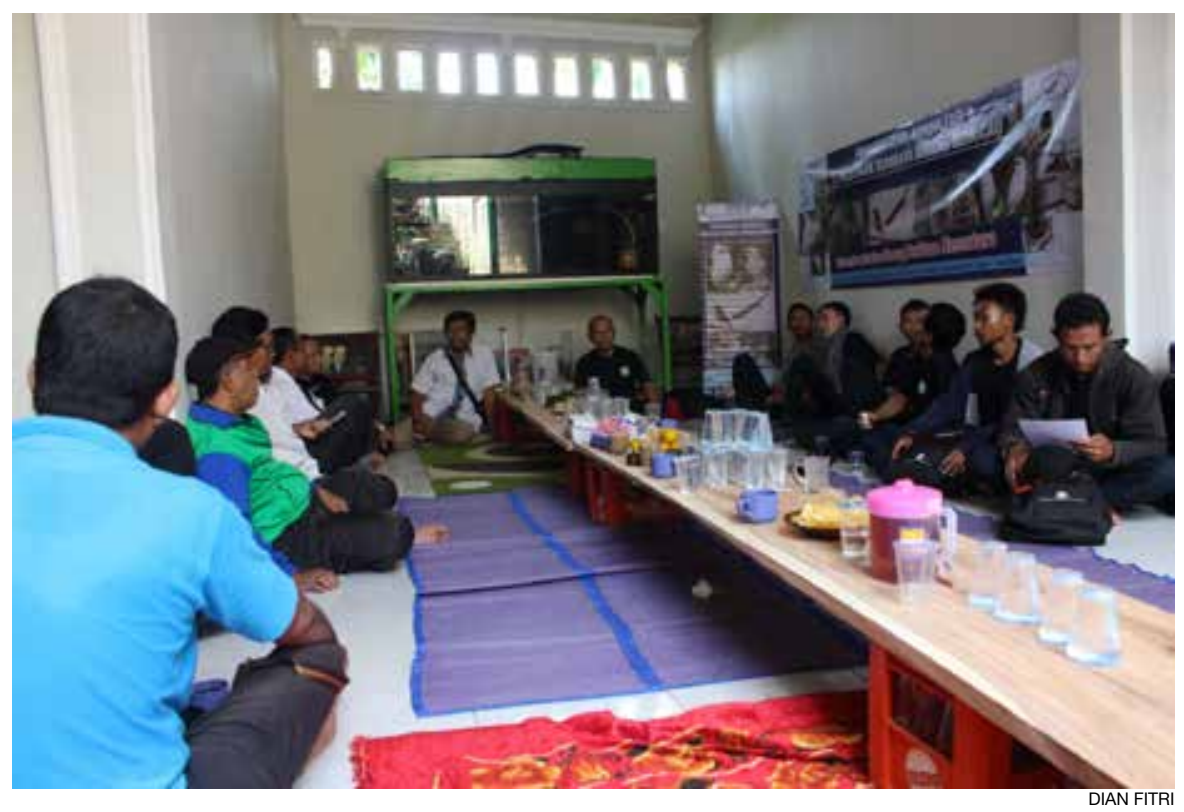

Foto 3. Diskusi antara Pengelola dan Masyarakat Tahura Djuanda

\section{Penutup}

Berdasarkan uraian di atas dapat disimpulkan; Pertama, faktor-faktor yang menyebabkan konflik yaitu dari pengelola, adanya perbedaan kebijakan antara Perum Perhutani dengan Balai Pengelolaan Tahura Djuanda, seringnya pergantian kepemimpinan, dan kurangnya sosialisasi antara pengelola dan masyarakat menyebabkan masyarakat kurang berpartisipasi aktif di dalam pengelolaan kawasan di Tahura Djuanda. Dari masyarakat yaitu adanya perbedaan latar belakang pendidikan, pola pikir masyarakat, dan pendapatan masyarakat. Bentuk-bentuk konflik yang terjadi, masyarakat menyalurkan ketidakpuasannya kepada pengelola dengan cara melakukan premanisme dan protes.

Kedua, implikasi konflik bagi pengelola adalah mengalami penurunan jumlah wisatawan, penurunan kualitas lingkungan akibat asap kendaraan roda dua yang melebihi kapasitas dan sampah plastik yang berasal dari pemukiman masyarakatsekitarTahura Djuanda, sertaterjadinyakesenjangan sosial dengan masyarakat akibat konflik yang terjadi. Sedangkan Implikasi positif dari konflik bagi pengelola adalah adanya peningkatan kesadaran terhadap lingkungan, artinya pengelola lebih peduli terhadap lingkungan sekitar kawasan Tahura Djuanda. Implikasi bagi masyarakat meliputi beberapa indikator yaitu penurunan pendapatan masyarakat yang berasal dari wisatawan dan berkurangnya jenis mata pencaharian dikarenakan tidak ada upaya untuk menambah keahlian melalui pelatihan program pemberdayaan masyarakat yang diselenggarakan oleh Balai Pengelolaan 
Tahura Djuanda.

Ketiga, solusi dalam mengatasi permasalahan yang terjadi dilakukan melalui strategi perencanaan program kegiatan, pengorganisasian kelembagaan, pengarahan kepada masyarakat, pengawasan pengelola Tahura Djuanda dan evaluasi setelah penerapan fungsi manajemen. Penyelesaiannya dilakukan dengan 3 tahap, yaitu negosiasi antara pengelola dengan masyarakat, mediasi pengelola, masyarakat, dan Dinas Kehutanan, dan arbitrasi oleh Dinas Kehutanan.

\section{Ucapan Terima Kasih}

Penulis menyampaikan terima kasih kepada Prof. Dr. I Nyoman Darma Putra, M.Litt, selaku Ketua Program Studi Magister Kajian Pariwisata Universitas Udayana dan Dr. Ir. Syamsul Alam Paturusi, MSP., sebagai Sekretaris Program Studi Magister Kajian Pariwisata Universitas Udayana. Ucapan terima kasih juga ditujukan kepada Prof. Dr. Drs. A.A. Ngurah Anom Kumbara. M.S. sebagai Pembimbing I, Dr. Ni Wayan Sukarini, M. Hum. selaku Pembimbing II, yang telah membimbing, mengarahkan, mendorong, dan memberikan semangat sehingga terselesainya artikel ini. Selain itu ucapan terima kasih juga disampaikan kepada para sahabat yang memberikan bantuan dan inspirasi dalam penulisan artikel ini.

\section{Daftar Pustaka}

Balai Pengelolaan. 2015. Company Profile Taman Hutan Raya Ir. H Djuanda. Bandung: Dinas Kehutanan Provinsi Jawa Barat

Boo, E. 1992. The Ecotourisme in The Boom WHN Technical Paper 2 Washington Dc: Wwf.

Fisher, S. et. al. 2001. Mengelola Konflik: Ketrampilan dan Strategi untuk Bertindak. S. N. Kartikasari. Penerjemah. Jakarta: The British Council.

Flippo, Edwin B. 2002. Personel Management (Manajemen Personalia), Edisi VII Jilid II, Terjemahan Alponso S. Jakarta: Erlangga.

Hasibuan, Malayu S.P. 2006. Manajemen Dasar, Pengertian, dan Masalah. Jakarta: Bumi Aksara.

Kartasasmita, Ginandjar. 1997. Pemberdayaan Masyarakat: Konsep Pembangunan yang berakar pada masyarakat. Disampaikan pada Sarasehan DPD GOLKAR Tk. I Jawa Timur, 14 Maret 1997.

Natori, Masahiko.2001. A Guidebook for Tourism Based Community Development. Yogyakarta Japan: APTEC

Sunaryo, Bambang. 2013. Kebijakan Pembangunan Destinasi Pariwisata Konsep dan aplikasinya di Indonesia. Yogyakarta: Gava Media.

Wardiyanto. 2011. Perencanaan \& Pengembangan Pariwisata. Bandung: Lubuk Agung. 


\section{Profil Penulis}

Dian Fitriyana, S.Par menyelesaikan pendidikan Magister Kajian Pariwisata di Universitas Udayana Denpasar Bali tahun 2015 Ia menyelesaikan program Diploma III Jurusan Usaha Perjalanan Wisata pada tahun 2007 di Universitas Padjadjaran Bandung dan Program Strata-1 Jurusan Management Resort and Leisure pada tahun 2011 di Universitas Pendidikan Indonesia Bandung. Pengalaman yang dimiliki di bidang pariwisata adalah pernah bekerja pada sebuah travel agent di Bandung, Jawa Barat. 